\title{
Sosialisasi Pemanfaatan Tenaga Surya Sebagai Sumber Energi Listrik Di Desa Ciherang Pondok, Kabupaten Bogor
}

\author{
Arief Suardi Nur Chairat ${ }^{1}$; Jasmid Eddy ${ }^{2}$; Vendy Antono ${ }^{3}$; Sahlan ${ }^{4}$; \\ Nofirman ${ }^{5}$; Michiel Martin Rumondor ${ }^{6}$ \\ 1, 2, 3, 4, 5, 6 Institut Teknologi PLN \\ ${ }^{1,5}$ Program Studi S1 Teknik Mesin, Fakultas Teknologi dan Bisnis Energi \\ 2,3,4,6 Program Studi DIII Teknik Mesin, Departemen Teknik Mesin \\ ${ }^{1}$ arief.suardi@itpln.ac.id
}

\begin{abstract}
One of the obstacles faced in providing electricity in rural areas is renewable energy sources, especially solar energy, which potentially in all rural areas also require inexpensive costs plus a lack of knowledge about these technologies. With a variety of goodness that exists in solar energy, counseling or socialization must be given about its utilization. Ciherang Pondok Village is located on a plateau in the area of Caringin District, Bogor Regency. The village is located at a strategic point, so it has enough light intensity to utilize solar power as a source of electrical energy. Extension activities are carried out by the lecture method to convey various general information about the use of solar power as a solution to the problem of electrical energy in the countryside. As a result, the knowledge of the local community increases and can apply directly independently how to use solar energy to be used as a source of electrical energy so that the availability of energy and people's access to energy are guaranteed at affordable prices in the long term while paying attention to environmental sustainability.
\end{abstract}

Keyword: Solar energy, electrical, village

\begin{abstract}
ABSTRAK
Salah satu kendala yang dihadapi dalam penyediaan listrik di pedesaan adalah sumber energi terbarukan, terutama energi surya, yang potensial di semua pedesaan juga memerlukan biaya yang tidak murah ditambah kurangnya pengetahuan tentang teknologi tersebut. Dengan beragam kebaikan yang ada pada energi surya, harus diberikan penyuluhan atau sosialisasi tentang pemanfaatannya. Desa Ciherang Pondok berada pada suatu dataran tinggi di wilayah Kecamatan Caringin, Kabupaten Bogor. Desa tersebut terletak di titik yang strategis, sehingga memiliki intensitas cahaya yang cukup untuk memanfaatkan tenaga surya sebagai sumber energi listrik. Kegiatan penyuluhan dilakukan dengan metode ceramah untuk menyampaikan berbagai informasi umum mengenai pemanfaatan tenaga surya sebagai solusi masalah energi listrik di pedesaan. Hasilnya pengetahuan masyarakat setempat bertambah dan dapat menerapkan langsung secara mandiri cara memanfaatkan energi surya untuk digunakan sebagai sumber energi listrik sehingga terjaminnya ketersediaan energi dan akses masyarakat terhadap energi pada harga yang terjangkau dalam jangka panjang dengan tetap memperhatikan kelestarian lingkungan hidup.
\end{abstract}

Kata Kunci: Energi surya, listrik, desa 


\section{PENDAHULUAN}

Tanpa keberadaan sumber energi, manusia akan kesulitan menjalankan roda kehidupan karena hampir semua aktivitas manusia membutuhkan energi. Manusia membutuhkan energi untuk aktivitas kehidupan sehari-harinya, mulai dari penggerak transportasi hingga aneka kebutuhan rumah tangga, seperti untuk memasak dan penerangan. Konsumsi energi Indonesia masih didominasi oleh bahan bakar minyak atau BBM (bensin, minyak solar, minyak diesel, dan minyak tanah). Pemanfaatan energi yang sifatnya berlebihan ini kemudian memicu terjadinya permasalahan krisis energi yang berdampak secara sistemik kepada semua aspek. Energi listrik merupakan kunci strategis dalam pemerataan keadilan sosial yang berefek kepada peningkatan taraf hidup masyarakat.

Indonesia adalah negara tropis yang hanya mengalami dua musim, panas dan hujan. Matahari akan bersinar sepanjang tahun, meskipun pada musim hujan intensitasnya berkurang. Kondisi iklim ini menyebabkan matahari dapat menjadi alternatif sumber energi masa depan di Indonesia. Jika aspek ini dapat kita manfaatkan sebaik mungkin, maka masyarakat pelosok maupun pedalaman yang ada di Indonesia juga dapat merasakan manfaat listrik sehari-hari. Sekarang ini, telah banyak ditemukan berbagai alternatif pembangkit tenaga listrik. Dengan keadaan geografis di Indonesia yang setiap tahun dapat sinar matahari, salah satu alat yang optimal di Indonesia adalah "Panel Surya". Panel surya bekerja mengubah energi cahaya matahari menjadi energi listrik. Panel Surya adalah alat yang terdiri dari sel surya, aki dan baterai yang mengubah cahaya menjadi listrik. Panel surya menghasilkan arus listrik searah atau DC.

Desa-desa di Indonesia umumnya menghadapi ancaman keterbelakangan dan ketidakadilan dalam hal pemerataan energi listrik. Kondisi ini disebabkan oleh belum tersedianya sumber daya manusia yang memadai dalam upaya memanfaatkan energi alternatif dengan baik serta pendanaan atau finansial yang mendukung dalam upaya mewujudkan ketahanan dan kemandirian energi di daerah pedesaan. Desa yang mampu mandiri energi dapat mengadopsi konsep distributed generation atau pembangkitan skala kecil tersebar yang semaksimal mungkin memanfaatkan energi terbarukan, dan dapat dibangun disekitar perumahan pedesaan atau komunitas masyarakat. Pengembangan sistem ini diharapkan dapat mengubah paradigma pembangunan di daerah untuk menunjang pemanfaatan sumberdaya yang tersedia secara efektif dan efisien. Desa Ciherang Pondok, Kecamatan Caringin, Kabupaten Bogor merupakan merupakan salah satu daerah yang belum memiliki infrastruktur kelistrikan yang baik. Dalam memenuhi kebutuhan energi listrik, masyarakat desa terkadang masih menggunakan genset yang kurang efisien dan mahal.

Potensi-potensi yang ada masih banyak yang belum tergarap dengan baik, terutama memanfaatkan sumberdaya alam untuk menghasilkan energi alternatif. Desa Ciherang Pondok berada pada suatu dataran tinggi di wilayah Kecamatan Caringin, Kabupaten Bogor. Desa tersebut terletak di titik yang strategis yaitu dengan koordinat lintang dan bujur 6 ${ }^{\circ} 39^{\prime} 55.53$ "S, 106 ${ }^{\circ} 56^{\prime} 42.56^{\prime \prime} \mathrm{E}$ sehingga memiliki intensitas cahaya yang cukup, selain itu desa Ciherang Pondok memiliki struktur tanah yang sangat bagus untuk pembangunan Pembangkit Listrik Tenaga Surya (PLTS). 


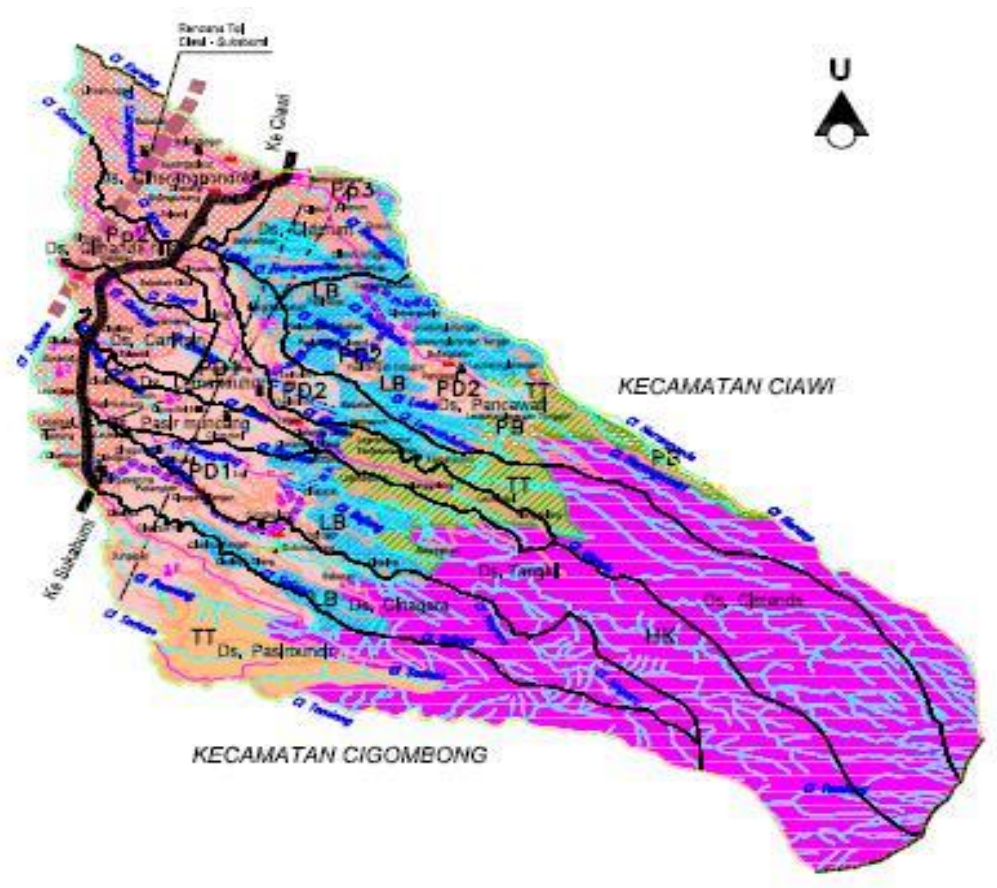

Gambar 1. Peta Wilayah Kecamatan Caringin

Keterbatasan dalam hal penyediaan energi listrik di desa Ciherang Pondok diantaranya adalah sumber energi terbarukan yang potensial di semua pedesaan memerlukan biaya yang tidak murah ditambah kurangnya pengetahuan masyarakat tentang teknologi tersebut karena alokasi anggaran pemerintah yang relatif kecil dibandingkan dengan luas wilayah. Terbatasnya sarana dan prasarana, teknologi pengolahan, mekanisme pengelolaan serta masih banyak masalah terutama terhadap lingkungan.

Potensi-potensi yang ada masih banyak yang belum tergarap dengan baik, terutama memanfaatkan tenaga surya untuk menghasilkan energi listrik. Intensitas cahaya matahari di desa Ciherang Pondok diperkirakan dapat menghasilkan energi yang sangat besar bila dimanfaatkan sebagai sumber energi listrik. Secara khusus target peserta kegiatan Pengabdian Kepada Masyarakat $(\mathrm{PKM})$ ini adalah:

a) Masyarakat Desa Ciherang Pondok serta masyarakat umum di daerah sekitar yang berprofesi sebagai tenaga teknik ketenagalistrikan., Kecamatan Caringin, Kabupaten Bogor, Provinsi Jawa Barat adalah mampu memanfaatkan tenaga surya secara optimal sebagai solusi alternatif untuk mengatasi permasalahan energi listrik. Masyarakat pedesaan memahami pemanfaatan tenaga surya untuk digunakan sebagai sumber energi listrik sehingga terjaminnya ketersediaan energi dan akses masyarakat terhadap energi pada harga yang terjangkau dalam jangka panjang dengan tetap memperhatikan kelestarian lingkungan hidup.

b) Dinas Energi dan Pertambangan, Kabupaten Bogor juga dapat terbantu karena dalam memberikan pemahaman kepada masyarakat tentang energi alternatif yang ramah lingkungan. Jika dapat dikembangkan ke rumah-rumah penduduk, dapat menghemat energi listrik terutama di daerah pedesaan. 
Kegiatan pengabdian kepada masyarakat ini didahului dengan survey pendahuluan untuk mengetahui potensi besar dari energi surya karena sosialisasi pengenalan energi surya kepada masyarakat yang masih lambat padahal telah diketahui jika indonesia memiliki potensi untuk mengoptimalkan sumber energi surya sebagai sumber energi alternatif yang baik.Dengan beragam kebaikan yang ada pada energi surya, sebenarnya ada masalah utama yang ada yaitu masyarakat masih tidak peduli tentang energi alternatif sebagai pengganti dan masih fokus untuk terus menggunakan energi dari bahan bakar fosil serta serta harga investasi awal untuk meggunakan sistem kerja fotovoltaik yang cukup mahal walau itu merupakan investasi jangka panjang yang cukup menguntungkan.

\section{METODE}

Untuk memanfaatkan potensi energi surya tersebut, ada 2 (dua) macam teknologi yang sudah diterapkan, serta kaitannya dengan metode dan teknologi yang akan digunakan, untuk tahapan implementasi yang lebih menyeluruh dan komprehensif adalah sebagai berikut:

A. Teknologi energi surya fotovoltaik, energi surya fotovoltaik digunakan untuk memenuhi kebutuhan listrik, pompa air, televisi, telekomunikasi, dan lemari pendingin dengan kapasitas total $\pm 6 \mathrm{MW}$. Salah satu cara penyediaan energi listrik alternatif yang siap untuk diterapkan secara masal pada saat ini adalah menggunakan suatu sistem teknologi yang diperkenalkan sebagai Sistem Energi Surya Fotovoltaik (SESF) atau secara umum dikenal sebagai Pembangkit Listrik Tenaga Surya Fotovoltaik (PLTS Fotovoltaik). Sebutan SESF merupakan istilah yang telah dibakukan oleh pemerintah yang digunakan untuk mengidentifikasikan suatu sistem pembangkit energi yang memanfaatkan energi matahari dan menggunakan teknologi fotovoltaik. Komponen utama suatu SESF adalah:

1) Sel fotovoltaik yang mengubah penyinaran/radiasi matahari menjadi listrik secara langsung (direct conversion). Teknologi sel fotovoltaik yang banyak dikembangkan dewasa ini pada umumnya merupakan jenis teknologi kristal yang dibuat dengan bahan baku berbasis silikon. Produk akhir dari modul fotovoltaik menyerupai bentuk lembaran kaca dengan ketebalan sekitar 6 - 8 milimeter;

2) Balance of system (BOS) yang meliputi controller, inverter, kerangka modul,peralatan listrik, seperti kabel, stop kontak, dan lain-lain, teknologinya sudah dapat dikuasai;

3) Unit penyimpan energi (baterai) sudah dapat dibuat di dalam negeri;

4) Peralatan penunjang lain seperti: inverter untuk pompa, sistem terpusat, sistem hibrid, dan lain-lain masih diimpor.

B. Teknologi energi surya termal, energi surya termal pada umumnya digunakan untuk memasak (kompor surya), mengeringkan hasil pertanian (perkebunan, perikanan, kehutanan, tanaman pangan) dan memanaskan air. Berbagai teknologi pemanfaatan energi surya termal untuk aplikasi skala rendah (temperatur kerja lebih kecil atau hingga $60^{\circ} \mathrm{C}$ ) dan skala menengah (temperatur kerja antara $60^{\circ}-120^{\circ} \mathrm{C}$ ) telah dikuasai dari rancangbangun, konstruksi hingga manufakturnya secara nasional. Secara umum, teknologi surya termal yang kini dapat dimanfaatkan termasuk dalam teknologi sederhana hingga madya. Beberapa teknologi untuk aplikasi skala rendah dapat dibuat oleh bengkel pertukangan kayu/besi biasa. Untuk aplikasi skala menengah dapat dilakukan oleh industri manufaktur nasional. Prospek teknologi energi surya termal cukup besar, terutama untuk mendukung peningkatan kualitas pasca-panen komoditi pertanian, untuk bangunan komersial atau perumahan di perkotaan. Prospek pemanfaatannya dalam sektor-sektor masyarakat, yaitu: 1) Industri, khususnya agro-industri dan industri pedesaan, yaitu untuk penanganan pasca- 
panen hasil-hasil pertanian, seperti: pengeringan (komoditi pangan, perkebunan, perikanan/peternakan, kayu olahan) dan juga pendinginan (ikan, buah dan sayuran);

2) Bangunan komersial atau perkantoran, yaitu: untuk pengkondisian ruangan ( Solar Passive Building, AC) dan pemanas air;

3) Rumah tangga, seperti: untuk pemanas air dan oven/ cooker;

4) PUSKESMAS terpencil di pedesaan, yaitu: untuk sterilisator, refrigerator vaksin dan pemanas air.

\section{HASIL DAN PEMBAHASAN}

Kegiatan sosialisasi Pemanfaatan Tenaga Surya Sebagai Sumber Energi Listrik Di Pedesaan telah dilaksanakan pada tanggal 10 - 11 Januari 2019. Kegiatan sosialisasi berjalan dengan lancar dihadiri oleh 28 peserta dari 30 undangan. Peserta sosialisasi terlihat antusias dengan materi yang diberikan. Hal ini terlihat dari awal hingga akhir acara, semua peserta mengikuti dengan baik.

Fokus kegiatan adalah memberikan informasi dan pengetahuan bagaimana cara masyarakat memanfaatkan tenaga surya sebagai sumber energi listrik. Matahari merupakan sumber energi utama yang memancarkan energi yang luar biasa besarnya ke permukaan bumi. Pada keadaan cuaca cerah, permukaan bumi menerima sekitar 1000Watt energi matahari per-meter persegi. Sebagian dari energi tersebut dipantulkan kembali ke angkasa, sebagian lagi dikonversikan menjadi panas, yang lainnya digunakan untuk seluruh sirkulasi kerja yang terdapat di atas permukaan bumi, sebagian kecil ditampung angin, gelombang dan arus dan masih ada bagian yang sangat kecil disimpan melalui proses fotosintesis pada tumbuh-tumbuhan yang akhirnya digunakan dalam proses pembentukan batu bara dan minyak bumi (bahan bakar fosil) yang saat ini digunakan secara ekstensif dan eksploratif bukan hanya untuk bahan bakar tetapi juga untuk bahan baku pembuat plastik, formika, bahan sintesis lainnya. Sehingga bisa dikatakan bahwa sumber segala energi adalah energi matahari. Pemanfaatan tenaga surya memalui konversi photovoltaic telah banyak diterapkanantara lain, penerapan sistem individu dan sistem hybrid yaitu sistem penggabungan antara sumber energi konvensional dengan sumber energi terbarukan. Fokus utama kegiatan adalah:

1) Sosialisasi teknologi energi surya fotovoltaik

Sel surya atau sering disebut fotovoltaik adalah sebuah perangkat yang mampu mengkonversikan cahaya matahari secara langsung untuk menjadi energi listrik.sel surya ini bisa disebut sebagai pemegang peran utama dalam memaksimalkan potensi sengat besar dari cahaya matahari yang sampai kebumu, selain dipergunakan untuk menghasilkan listrik, energi matahari juga dimanfaatkan dari segi panasnya melalui sistem solar thermal. Seiring dengan perkembangan sains dan teknologi saat ini, jenis-jenis teknologi dari sel suryajuga berkembang dengan berbagai inovasi. Sel surya yang umum berada dipasaran saat ini yaitu sel surya berbasis material silikon yang juga secara umum mencakup struktur dan cara kerja sel surya generasi pertama (sel surya silikon) dan kedua (lapisan tipis). Kerja sel surya sendiri sebenarnya identik dengan konsep semikonduktor dioda. Ketika cahaya bersentuhan dengan sel surya dan diserap oleh bahan semikonduktor, terjadi pelepasan elektron. Apabila elektron tersebut bisa menempuh perjalanan menuju bahan semikonduktor pada lapisan yang berbeda, terjadi perubahan sigma gaya-gaya pada bahan. Gaya tolakan antar bahan semikonduktor, menyebabkan aliran medan listrik. Dan menyebabkan elektron dapat disalurkan ke saluran awal dan akhir untuk digunakan pada perabot listrik. Lampu terdeteksi oleh sensor menghadap ke arah timur berada pada intensitas yang lebih rendah dengan yang terdeteksi oleh sensor menghadap ke barat. Oleh karena itu, panel surya harus diubah ke arah barat (oleh motor dikontrol oleh rangkaian 
solar tracker) sampai tingkat cahaya terdeteksi baik oleh Timur dan Barat sensor adalah sama. Pada saat itu panel surya akan langsung menghadap matahari dan listrik yang dihasilkan optimal.

2) Sistem Pembangkit Listrik Tenaga Surya (PLTS)

Dalam dunia kelistrikan, sistem PLTS secara garis besar dapt dibagi menjadi tiga, yaitu:

a) Off Grid System, merupakan sistem pembangkit listrik alternatif untuk daerah-daerah terpencil yang tidak terjangkauoleh jaringan PLN.sistem ini disebut juga dengan standalone PV sistem, yaitu sistem pembangkit listrik yang hanya mengandalkan energi matahari sebagai satu-satunya sumber energi utama dengan menggunakan rangkaian fotovoltaik modul untuk menghasilkan energi listrik sesuai dengan kebutuhan.

b) On Grid/Grid Tie System, sistem ini menggunakan solar panel (panel fotovoltaik) untuk menghasilkan listrik yang ramah lingkungan dan bebas emisi. Dengan adanya sistem ini akan mengurangi tagihan listrik rumah tangga dan memberikan nilai tambah pada pemiliknya. Rangkaian ini akan tetap terhubung dengan jaringan PLN dengan mengoptimalkan pemanfaatan energi dari panel surya untuk menghasilkan energi listrik semaksimal mungkin.

c) Hybrid System, sistem ini menggunakan dua sistem atau lebih pembangkit listrik dengan sumber energi yang berbeda. Umumnya sistem pembangkit yang banyak digunakan untuk hybrid adalah genset, PLTS, mikrohydro dan tenaga angin. Sistem ini merupakan salh satu alternatif sistem pembangkit yang tepat untuk diaplikasikan pada daerahdaerah yang sukar dijangkau oleh sistem pembangkit besar seperti jaringan PLN maupun Pemabngkit Listrik Tenaga Diesel (PLTD). Sistem hybrid ni memanfaatkan renewable energi sebagai sumber utama (primer) yang dikombinasikan dengan genset atau lainnya sebagai sumber energi cadangan.

Berikut ini disajikan beberapa dokumentasi kegiatan pelaksanaan pelatihan dengan metode ceramah yang dilakukan.
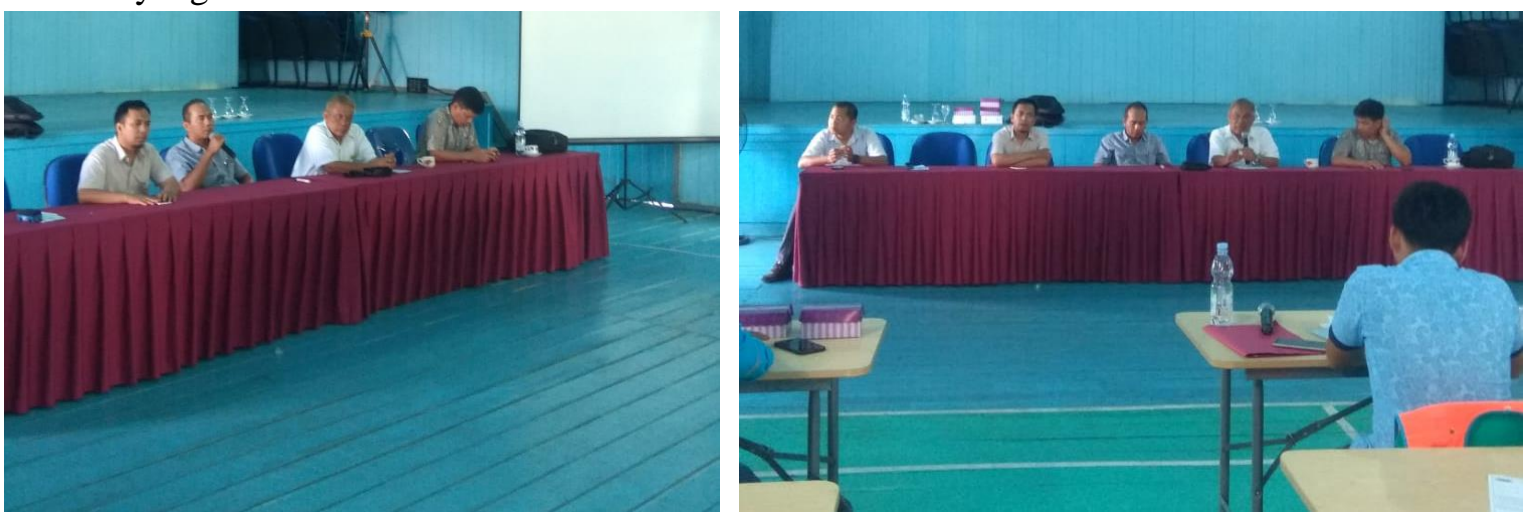

Gambar 2. Sambutan Kepala Desa Ciherang Pondok dan Ketua Tim PkM IT-PLN 


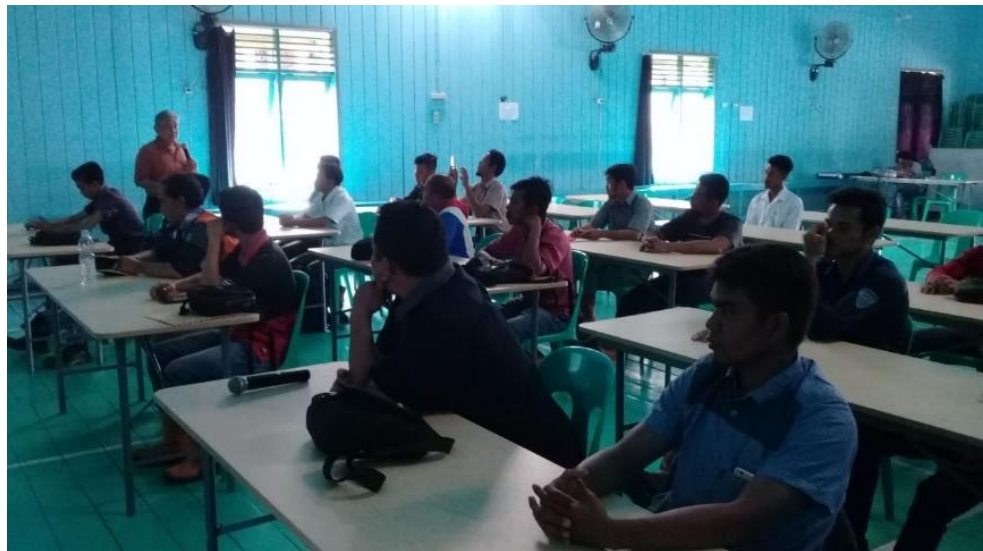

Gambar 3. Sosialisasi Dengan Masyarakat Desa Ciherang Pondok

\section{KESIMPULAN}

Mengacu pada rancangan kegiatan dan berdasarkan dari hasil kegiatan sosialisasi dapat dihasilkan beberapa kesimpulan, yaitu:

1) Sosialisasi pemanfaatan tenaga surya sebagai sumber energi listrik di pedesaan bagi masyarakat desa Ciherang Pondok, Kabupaten Bogor, secara positif berdampak pada masyarakat dan para tenaga teknik dapat mengenal dan mengetahui potensi dan bagaimana cara pemanfaatan energi/tenaga surya sebagai sumber energi listrik serta prinsip kerja sel surya di daerah pedesaan.

2) Masyarakat setempat dapat mengambil manfaat dari adanya kegiatan ini, yaitu pengetahuan tentang prinsip kerja sel surya dan pemanfaatan tenaga surya untuk digunakan sebagai energi listrik sehingga terjaminnya ketersediaan energi dan akses masyarakat terhadap energi pada harga yang terjangkau dalam jangka panjang dengan tetap memperhatikan kelestarian lingkungan hidup.

\section{SARAN}

Mengacu pada rancangan kegiatan dan berdasarkan dari hasil kegiatan sosialisasi dapat dihasilkan beberapa saran untuk perbaikan kegiatan selanjutnya, yaitu:

1) IT-PLN perlu lebih menggalakkan dan meingkatkan program sosialisasi pemanfaatan tenaga/energi surya sebagai sumber energi listrik, khususnya bagi masyarakat di daerah pedesaan.

2) Dukungan Pemerintah daerah juga diharapkan karena tidak memerlukan biaya yang besar untuk membuat suatu pembangkit listrik fotovoltaik, atau harus membangun transmisi pembangkit baru, karena dapat menggunakan transmisi yang sudah dipasang oleh PLN.

\section{UCAPAN TERIMA KASIH}

Dengan terlaksananya kegiatan ini Tim PkM mengucapkan terima kasih kepada Kepala LPPM IT-PLN, Kepala Desa Ciherang Pondok, Kecamatan Caringin, Kabupaten Bogor, Jawa Barat, dan masyarakat Desa Ciherang Pondok atas pastisipasi serta bantuannya yang tidak ternilai sehingga semua rencana kegiatan PkM pada semester Gasal Tahun Akademik 2018/2019 ini telah terlaksana dengan baik. Demikian Laporan akhir kegiatan pelaksanaan Pengabdian Pada Masyarakat ini dibuat. 


\section{DAFTAR PUSTAKA}

[1] Anonim. 2014. Pengertian Energi Terbarukan. Diakses pada tanggal 26 Juli 2016 dari http://www.indoenergi.com/2012/04/pengertian-energi-terbarkan.html

[2] Marsudi, Djiteng (2005). Pembangkitan Energi Listrik. Jakarta: Erlangga.

[3] Michaels, T. and I. Shiang 2016. Energy Recovery Council 2016 Directory of Waste-ToEnergy Facilities.

[4] Rif'an, M. Sholeh HP. Shidiq, Mahfudz. Yuwono, Rudy. Suyono, Hadi. Fitriana. (2012). Optimasi Pemanfaatan Energi Listrik Tenaga Matahari di Jurusan Teknik Elektro Universitas Brawijaya.

[5] Stevanus, Widianto (2011). Sistem Intalasi PLTS 1000 Wp Sitting Ground Teknik Elektro UNDIP Semarang. Makalah disampaikan pada seminar kerja praktek UNDIP jurusan Teknik Elektro, Fakultas Teknik UNDIP. Semarang. 